\title{
Immunoproteomics based identification of thioredoxin reductase GliT and novel Aspergillus fumigatus antigens for serologic diagnosis of invasive aspergillosis
}

Li-ning Shi, Fang-qiu Li*, Mei Huang, Jing-fen Lu, Xiao-xiang Kong, Shi-qin Wang and Hai-feng Shao

\begin{abstract}
Background: There has been a rising incidence of invasive aspergillosis (IA) in critically ill patients, even in the absence of an apparent predisposing immunodeficiency. The diagnosis of IA is difficult because clinical signs are not sensitive and specific, and serum galactomannan has relatively low sensitivity in this group of patients. Therefore, more prompt and accurate disease markers for early diagnosis are needed. To establish disease markers demands a thorough knowledge of fungal antigens which may be detected in the serum or other body fluids of patients. Herein we report novel immunodominant antigens identified from extracellular proteins of Aspergillus fumigatus.

Results: Extracellular proteins of A. fumigatus were separated by two-dimensional electrophoresis (2-DE) and probed with the sera from critically ill patients with proven IA. The immunoreactive protein spots were identified by MALDI-TOF mass spectrometry (MALDI-TOF -MS). Forty spots from 2DE gels were detected and 17 different proteins were identified as immunogenic in humans. Function annotation revealed that most of these proteins were metabolic enzymes involved in carbohydrate, fatty acid, amino acid, and energy metabolism. One of the proteins, thioredoxin reductase GliT (TR), which showed the best immunoactivity, was analyzed further for secretory signals, protein localization, and homology. The results indicated that TR is a secretory protein with a signal sequence exhibiting a high probability for secretion. Furthermore, TR did not match any human proteins, and had low homology with most other fungi. The recombinant TR was recognized by the sera of all proven IA patients with different underlying diseases in this study.

Conclusions: The immunoreactive proteins identified in this study may be helpful for the diagnosis of IA in critically ill patients. Our results indicate that TR and other immunodominant antigens have potential as biomarkers for the serologic diagnosis of invasive aspergillosis.
\end{abstract}

\section{Background}

In recent decades, invasive aspergillosis (IA) has emerged as an important cause of morbidity and mortality in patients with prolonged neutropenia. However, several reports have recently described a rising incidence of IA in critically ill patients, even in the absence of an apparent predisposing immunodeficiency [1-6]. The incidence of IA in critically ill patients ranges from $0.3 \%$ to $5.8 \%$

\footnotetext{
*Correspondence: njlifq@163.com

Laboratory of Molecular Biology, Institute of Medical Laboratory Sciences, Jinling Hospital, School of Medicine, Nanjing University, 305 East Zhongshan Road, Nanjing 210002, PR China
}

() 2012 Shi et al; licensee BioMed Central Ltd. This is an Open Access article distributed under the terms of the Creative Commons Attribution License (http://creativecommons.org/licenses/by/2.0), which permits unrestricted use, distribution, and reproduction in any medium, provided the original work is properly cited.
$[2,3,6]$, and carries an overall mortality rate $>80 \%$, with an attributable mortality of approximately $20 \%[4,5]$. Critically ill patients are prone to develop immunologic derangement, which renders them more vulnerable for Aspergillus infections. The risk factors for IA include chronic obstructive pulmonary disease (COPD) and other chronic lung diseases $[1-4,7,8]$, prolonged use of steroids [2,9], advanced liver disease [2-4,10], chronic renal replacement therapy $[11,12]$, near-drowning [4,13-15], and diabetes mellitus [2,3,9].

The diagnosis of such IA is difficult because signs and symptoms are non-specific. The conventional diagnostic 
methods, such as tissue examination and microbial cultivation, may lack sensitivity in the first stages of infection in critically ill patients. As a result, the diagnosis of IA is often established after a long delay or following autopsy. Currently, the best-characterized circulating marker used in the diagnosis of IA is galactomannan (GM), which is present in the cell walls of most Aspergillus species. The commercial Platelia Aspergillus assay (BioRad ${ }^{\mathrm{TM}}$, Marnes-La-Coquette, France) has been included in the EORTC/MSG criteria for probable IA. However, a recent meta-analysis indicated that GM testing is more useful in patients with prolonged neutropenia (sensitivity, $72 \%-82 \%$ ) than in non-neutropenic, critically ill patients (sensitivity, 40\%-55\%) [16]. Further studies suggested that the host immune status may influence GM release. It appears that GM production is proportional to the fungal load in tissues [17]. Although neutropenic patients and non-neutropenic, critically ill patients are susceptible to IA, the pathology of the disease is quite different in these two groups of patients. In neutropenic patients and animal models, IA is characterized by thrombosis and hemorrhage from rapid and extensive hyphal growth [18]. However, in non-neutropenic, critically ill patients and animal models, IA is characterized by limited angioinvasion, tissue necrosis, and excessive inflammation [18,19]. The limited angioinvasion and low fungal load result in a low level of GM released by the fungus. The use of the GM assay for the diagnosis of IA in non-neutropenic patients is very limited. Therefore, more prompt and accurate disease markers for early diagnosis are needed, which requires a thorough knowledge of fungal antigens detected in the serum or other body fluids of infected patients.

A. fumigatus is the most common opportunistic pathogen that causes life-threatening IA in human beings. The ability of $A$. fumigatus to acquire and process growth substrates from its host is dependent on factors released from the fungi. The extracellular proteins of $A$. fumigatus, which are released during the germination of conidia and growth of hyphae, consist of secreted enzymes, toxins, and other secondary metabolites which are pathogenic and responsible for invasion of the structural barrier of the host [20]. Studies on the extracellular proteins of A. fumigatus and their immunogenic potential are therefore important for further understanding the pathogenesis of A. fumigatus and targets for the immunodiagnosis of the diseases. It is not surprising that some of the proteins may be major elicitors of specific immune responses, which could be brought into play to establish prognosis and develop new diagnostic procedures for IA.

We have recently observed that high levels of antibody against extracellular proteins of $A$. fumigatus are often present in the sera of critically ill patients with proven IA. This finding prompted us to discover the potential novel biomarkers for the diagnosis of IA in such patients. The investigation of specific antigens is strongly supported by the combination of immunoproteomics and bioinformatics. The completion of the genomes of A. fumigatus [21] and other Aspergillus species [22-25] makes it possible to identify the antigens of Aspergillus species on a global scale. In this study we searched for the immunodominant antigens from the crude culture filtrate using an immunoproteomic approach. As a result, a total of 17 immunodominant antigens were identified. One of the antigens, thioredoxin reductase GliT (TR), which showed the best immunoactivity, was cloned and expressed in Escherichia coli. Our results indicate that this protein could be useful for the early diagnosis of IA.

\section{Results}

\section{Characterization of the patients}

Six patients with proven IA, and different underlying diseases and expressing high levels of anti-Aspergillus antibodies were selected for the immunoproteomic analysis. The details of the characteristics of the six patients with proven IA are listed in Table 1, histopathological results are given in Additional file 1 and the Western blots are shown in Figure 1. Multiple bands of immunogenic proteins were observed in each case, but not in the control sera. The enzyme-linked immunosorbent assay (ELISA) values of the patients with proven IA and the controls ranged from 1.105 to 2.561 and 0.114 to 0.362 , respectively.

\section{Identified immunoreactive proteins}

The 2-DE and Western blot analyses of the filtrate proteins are shown in Figure 2. A total of 40 distinct immunoreactive spots were identified. The 39 successfully identified spots corresponded to 17 individual proteins. The sequence coverage ranged from $18 \%-70 \%$, and the MASCOT scores were from 68 to 258. The identified proteins with molecular weights, isoelectric points, Mascot scores, and sequence coverage are listed in Table 2 (MS data of all immunoreactive spots identified are shown in Additional file 2). Several proteins occurred in multiple spots. Post-translational modifications are a likely explanation, resulting in altered molecular masses and/or isoelectric points. All 17 proteins are shown as a protein spot on the 2-DE gel and a corresponding immunogenic spot on the matching film. Of 17 identified proteins, 14 were matched with A. fumigatus (Af 293), and 3 showed homology to proteins from another Aspergillus species. Most of these proteins are metabolic enzymes that are involved in carbohydrate, fatty acid, amino acid, and energy metabolism. Seven of these proteins have been reported as antigens of Aspergillus and other fungi, and others have not been described as antigens before, such as fumarylacetoacetate hydrolase FahA, aldehyde dehydrogenase AldA, aromatic aminotransferase Aro8, 
Table 1 Clinical characteristics of proven IA patients

\begin{tabular}{|c|c|c|c|c|c|c|c|c|}
\hline Patient & $\begin{array}{l}\text { Age } \\
\text { (years) }\end{array}$ & sex & underlying disease & $\begin{array}{l}\text { Immunosuppressant } \\
\text { agents }\end{array}$ & $\begin{array}{l}\text { Infected } \\
\text { site }\end{array}$ & $\begin{array}{l}\text { Patients } \\
\text { outcome }\end{array}$ & $\begin{array}{l}\text { Culture sample } \\
\text { and result }\end{array}$ & Histo evidence \\
\hline 1 & 30 & Female & $\begin{array}{l}\text { systemic lupus } \\
\text { eythematosus, } \\
\text { lupus nephritis }\end{array}$ & Methylprednisolone & lung & Alive & $\begin{array}{l}\text { Sputum, } \\
\text { A. fumigatus }\end{array}$ & $\begin{array}{l}\text { Percutaneous lung } \\
\text { biopsy }\end{array}$ \\
\hline 2 & 39 & Male & Shock, previously healthy & None & lung & Alive & $\begin{array}{l}\text { BAL, } \\
\text { A. fumigatus }\end{array}$ & Transbronchial biopsy \\
\hline 3 & 62 & Male & $\mathrm{DM}, \mathrm{HP}$ & None & lung & Dead & $\begin{array}{l}\text { Sputum, } \\
\text { A. fumigatus }\end{array}$ & $\begin{array}{l}\text { Percutaneous lung } \\
\text { biopsy }+ \text { autopsy }\end{array}$ \\
\hline 4 & 44 & Male & near-drowning & None & lung & Alive & $\begin{array}{l}\text { BAL, } \\
\text { A. fumigatus }\end{array}$ & Transbronchial biopsy \\
\hline 5 & 56 & Female & $\begin{array}{l}\text { Chronic obstructive } \\
\text { pulmonary disease }\end{array}$ & Methylprednisolone & lung & Alive & $\begin{array}{l}\text { BAL, } \\
\text { A. fumigatus }\end{array}$ & Transbronchial biopsy \\
\hline 6 & 65 & Male & renal transplantation & $\begin{array}{l}\text { Prednisone, } \\
\text { mycophenolate }\end{array}$ & lung & Alive & $\begin{array}{l}\text { BAL, } \\
\text { A. fumigatus }\end{array}$ & Transbronchial biopsy \\
\hline
\end{tabular}

Abbreviations: $\mathrm{BAL}=$ bronchoalveolar lavage

G-protein comlpex beta subunit $\mathrm{CpcB}$, actin cytoskeleton protein (VIP1), phytanoyl-CoA dioxygenase family, urate oxydase UaZ, 3-hydroxybutyryl-CoA dehydrogenase, proteasome component Pre8, putative and hypothetical protein. One protein of interest, which showed the best immunoreactivity, was identified as TR.

\section{Bioinformatics analysis of TR}

TR was predicted as a secretory protein with the presence of signal sequences with good predictive value (signalP probability, 0.808). The protein localization of TR was predicted using WoLF PSORT, and the result also indicated that this protein might be an extracellular protein (Query
Protein WoLFPSORT prediction: extr, 12.0; cyto, 6.5; cyto_nucl, 4.0; mito, 3.0; pero, 2.0). This protein was BLAST-searched for sequence homology with human proteins and other fungi using the BLAST program (http:// www.ncbi.nlm.nih.gov/BLASTp). The results indicated that TR of A. fumigatus had no matches with human proteins. Furthermore, TR of $A$. fumigatus had low homology with other fungi, such as Candida albicans (25\%), C. tropicalis (25\%), C. glabrata (24\%), C. guilliermondii (27\%), C. dubliniensis (23\%), Saccharomyces cerevisiae (24\%), Cryptococcus neoformans (28\%), and Penicillium marneffei (27\%). This protein was also BLAST-searched for sequence homology with all protein databases using the

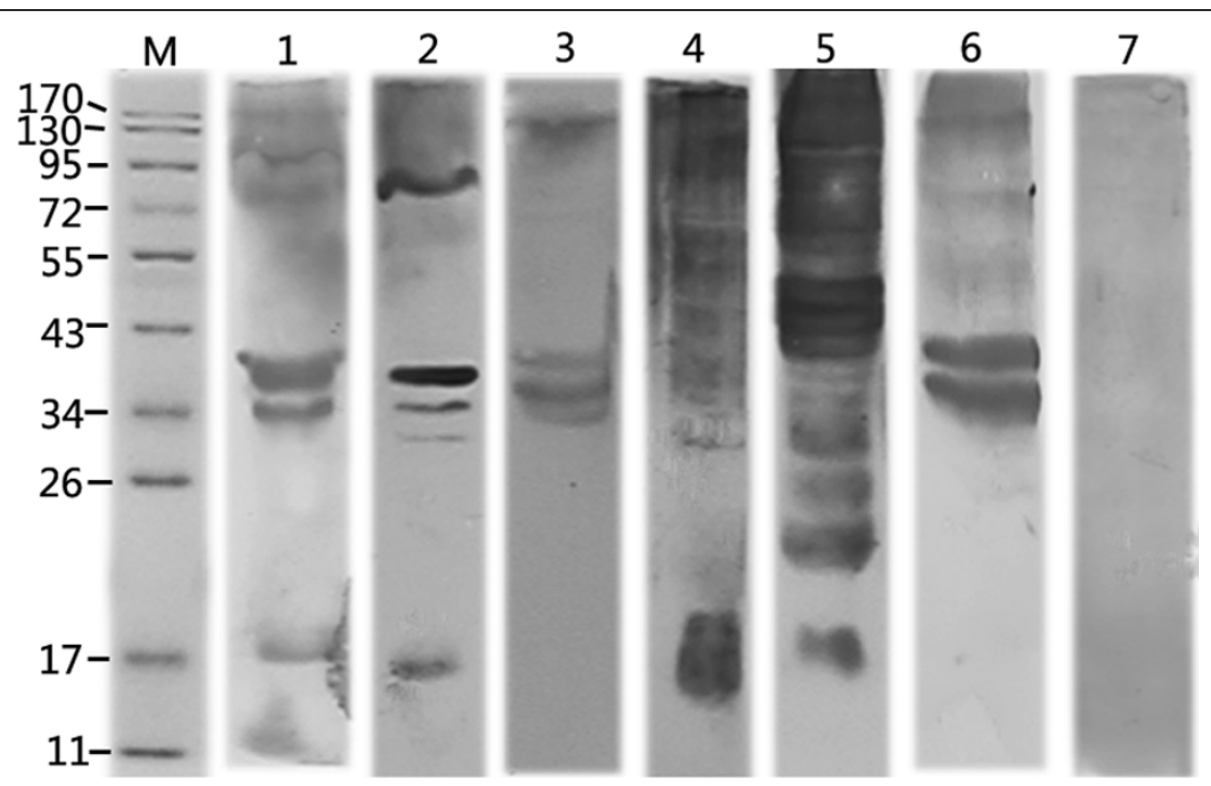

Figure 1 Western blot analysis of $\boldsymbol{A}$. fumigatus extracellular proteins and sera of proven IA patients. Filtrate proteins (10 $\mu \mathrm{g})$ of $A$. fumigatus during growth in YEPG medium at $37^{\circ} \mathrm{C}$ for 14 days were separated by SDS-PAGE and probed with sera from 6 patients with proven IA and control patients. Lane M, molecular weight marker; lanes 1-6, shows Western blot with sera from each of 6 proven IA patients; lane 7 , shows Western blot with pooled sera of control patients. 


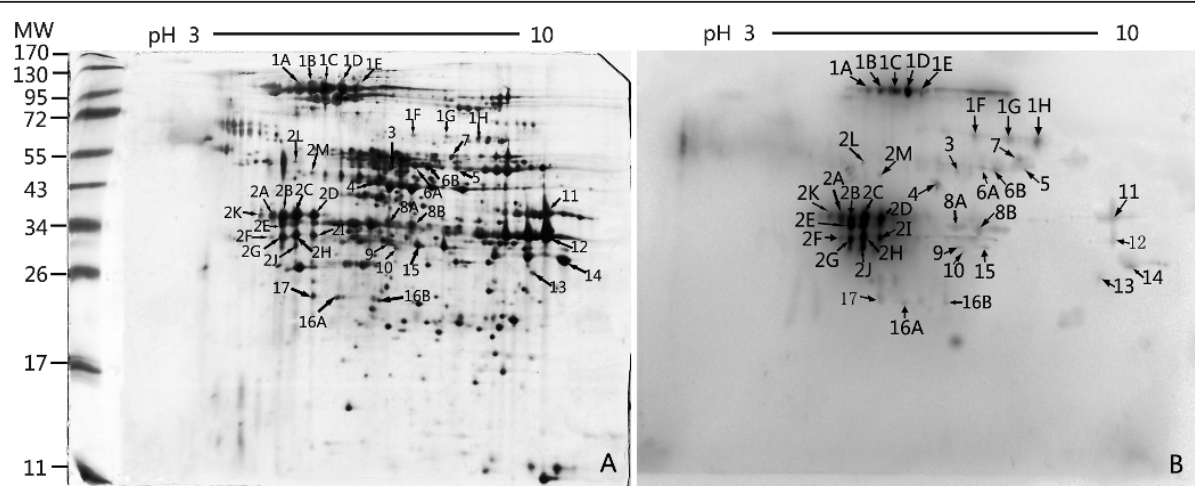

Figure 2 2-DE analysis and Western blot for identification of immunogens from filtrate proteins of $A$. fumigatus. (A) 2-DE of filtrate proteins of $A$. fumigatus during growth in YEPG medum at $37^{\circ} \mathrm{C}$ for 14 days. (B) Immunoblot using pooled sera from proven IA patients. Filtrate proteins $(150 \mu \mathrm{g})$ were separated by isoelectric focusing on Immobiline Dry strips (pH range, 3-10) followed by SDS-PAGE and silver staining. Standard molecular mass markers are indicated. Distinct protein spots $(n=39)$ with specific lgG immunoreactivity, as seen in corresponding immunoblots (B), were subjected to tryptic digestion followed by MALDI-TOF-MS analysis for identification (marked with arrow). The 17 proteins identified are numbered and listed in Table 2. Spot No. 2A-2 M was identified as thioredoxin reductase GliT.

Uniprot program (http://www.uniprot.org). The results indicated that TR of A. fumigatus has < 55\% homology with all proteins in the databases, excluding pyridine nucleotide-disulphide oxidoreductase of $A$. fischeri (identitiy, 94\%) and the putative uncharacterized protein of A. terreus (identitity, $80 \%$ ). TR of $A$. fumigatus also had low homology with most other Aspergillus species, such as A. oryzae (55\%), A. flavus (54\%), A. nidulans (50\%), A. clavatus (47\%), and A. niger (41\%), as shown in Additional file 3.

\section{Expression and antigenicity of TR recombinant protein}

After induction by isopropyl- $\beta$-D-thiogalactoside (IPTG), the recombinant 6-His-tagged TR was expressed, and a novel protein band corresponding to $36 \mathrm{kDa}$ was detected by SDS-PAGE (Figure 3A). Most of the recombinant proteins were soluble. After purification using a TALON metal affinity resin, the protein purity was approximately $91 \%$. Protein identity was unambiguously confirmed by MALDI-TOF MS, whereas following tryptic digestion proteins were identified yielding $37 \%$ sequence coverage (the MS spectra are shown in Additional file 4). Western blot showed that the recombinant proteins could be recognized by the sera from all six patients with proven IA (Figure 3B).

\section{Discussion}

Aspergillus fumigatus is known as the most common cause of IA in humans. The extracellular proteins of A. fumigatus, which functions in enabling the fungi to adhere to host tissues and take up nutrients from the hosts, play an important role in the interaction between fungi and hosts. The extracellular location of these proteins enables the proteins to interact easily with the host immune system. Accordingly, studies on the immunogenic nature of these extracellular proteins are of particular importance to understand the pathogenesis of $A$. fumigatus. The immunogenic proteins may represent candidate markers for the diagnosis of IA. In fact, preparations of A. fumigatus extracellular proteins have been used to detect antibodies in the sera of human patients or experimentally infected animals, and culture filtrates have also been used to raise polyclonal antibodies to detect $A$. fumigatus antigens in the sera or urine of patients or experimentally infected rats [26,27]. Our group has previously observed that high titers of antibodies against extracellular proteins of $A$. fumigatus are often present in the sera of critically ill IA patients (unpublished data). However, knowledge of the extracellular proteins of A. fumigatus and the corresponding antibodies is limited. To investigate the immunodominant antigens, the extracellular proteins at different intervals were extracted from 4 media (Aspergillus minimal medium, YEPG, Czapek-Dox medium, and RPMI-1640), then probed with sera of IA patients. The results indicated that the protein yield reached a maximum at 14 days, and the YEPG culture supernatant contained the maximum number of proteins reacting with the sera in comparison to other media (unpublished data). Thus, the 14-day YEPG filtrate proteins were used in a subsequent study.

In the present study, the immunodominant proteins from the culture filtrate of A. fumigatus were detected using an immunoproteomic approach. The immunoreactive protein spots showing a significantly different pattern of recognition in sera from IA patients when compared with specimens from controls were characterized by MS. Of 17 identified proteins, 7 have been reported as antigens of Aspergillus and/or other fungi. For example, DppV, TR, FAD-dependant oxygenase, pectate lyase A, aspartyl aminopeptidase, and NAD-dependent malate dehydrogenase are already known as antigens or allergens of Aspergillus [28-31]. Fructose-bisphosphate aldolase was identified as 
Table 2 Immunoreactive proteins of A.fumigates identified by MALDI-TOF-MS

\begin{tabular}{|c|c|c|c|c|c|c|c|c|c|}
\hline $\begin{array}{l}\text { Spot } \\
\text { no. }\end{array}$ & $\begin{array}{l}\text { Accession No. } \\
\text { (GenBank) }\end{array}$ & Organism & Protein name & $\begin{array}{l}\text { Peptides } \\
\text { matched }\end{array}$ & $\begin{array}{l}\text { Sequence } \\
\text { coverage(\%) }\end{array}$ & $\begin{array}{l}\text { Mascot } \\
\text { score }\end{array}$ & $\begin{array}{l}\text { BLAST score } \\
\text { (E-value) }\end{array}$ & $\begin{array}{l}\text { Theoretical } \\
\mathrm{pl} / \mathrm{Mr}(\mathrm{kDa})\end{array}$ & Probable functions \\
\hline $\begin{array}{l}1 \mathrm{~A}- \\
1 \mathrm{H}\end{array}$ & Gl:71001112 & $\begin{array}{l}\text { Aspergillus } \\
\text { fumigatus Af293 }\end{array}$ & $\begin{array}{l}\text { secreted dipeptidyl } \\
\text { peptidase DppV }\end{array}$ & 26 & 33 & 135 & 1.60E-08 & $5.59 / 79.7$ & Metabolism of dipeptides \\
\hline $\begin{array}{l}2 A- \\
2 M\end{array}$ & Gl:70992029 & $\begin{array}{l}\text { Aspergillus } \\
\text { fumigatus Af293 }\end{array}$ & $\begin{array}{l}\text { thioredoxin reductase } \\
\text { GliT }\end{array}$ & 20 & 54 & 149 & $6.30 \mathrm{E}-10$ & $5.44 / 36.2$ & Provide self-protection to A. fumigatus \\
\hline 3 & Gl:159123228 & $\begin{array}{l}\text { Aspergillus } \\
\text { fumigatus A1163 }\end{array}$ & $\begin{array}{l}\text { FAD dependent } \\
\text { oxidoreductase, putative }\end{array}$ & 25 & 44 & 173 & $2.50 \mathrm{E}-12$ & $5.94 / 51.5$ & Oxidoreductase \\
\hline 4 & Gl:70989411 & $\begin{array}{l}\text { Aspergillus } \\
\text { fumigatus Af } 293\end{array}$ & $\begin{array}{l}\text { fumarylacetoacetate } \\
\text { hydrolase FahA }\end{array}$ & 13 & 37 & 85 & 0.0015 & $5.95 / 46.9$ & Phenylalanine catabolism, Tyrosine catabolism \\
\hline 5 & Gl: 119492487 & $\begin{array}{l}\text { Neosartorya } \\
\text { fischeri NRRL } 181\end{array}$ & aspartyl aminopeptidase & 20 & 40 & 98 & $8.90 \mathrm{E}-05$ & $6.03 / 53.9$ & proteolysis, tissue invasion \\
\hline $\begin{array}{l}6 A- \\
6 B\end{array}$ & Gl: 70992355 & $\begin{array}{l}\text { Aspergillus } \\
\text { fumigatus Af293 }\end{array}$ & $\begin{array}{l}\text { aldehyde dehydrogenase } \\
\text { AldA }\end{array}$ & 25 & 54 & 171 & $4.00 \mathrm{E}-12$ & $6.30 / 61.4$ & Alcohol metabolism \\
\hline 7 & Gl: 71002030 & $\begin{array}{l}\text { Aspergillus } \\
\text { fumigatus Af293 }\end{array}$ & $\begin{array}{l}\text { aromatic } \\
\text { aminotransferase Aro8 }\end{array}$ & 19 & 52 & 145 & $3.10 \mathrm{E}-08$ & $5.96 / 58.3$ & Aromatic aminoacid family metabolic process \\
\hline $\begin{array}{l}8 \mathrm{~A}- \\
8 \mathrm{~B}\end{array}$ & Gl: 70999466 & $\begin{array}{l}\text { Aspergillus } \\
\text { fumigatus Af293 }\end{array}$ & $\begin{array}{l}\text { fructose-bisphosphate } \\
\text { aldolase, class II }\end{array}$ & 19 & 62 & 137 & 9.90E-09 & $5.55 / 39.9$ & Glycolysis, Carbohydrate degradation \\
\hline 9 & Gl: 119499942 & $\begin{array}{l}\text { Neosartorya } \\
\text { fischeri NRRL } 181\end{array}$ & $\begin{array}{l}\text { G-protein comlpex beta } \\
\text { subunit } C p c B\end{array}$ & 18 & 59 & 130 & 5.00E-08 & $6.06 / 35.3$ & $\begin{array}{l}\text { Receptor signaling, intracellular signal transduction } \\
\text { pathways, and protein synthesis }\end{array}$ \\
\hline 10 & Gl: 71001310 & $\begin{array}{l}\text { Aspergillus } \\
\text { fumigatus Af } 293\end{array}$ & $\begin{array}{l}\text { actin cytoskeleton } \\
\text { protein (VIP1) }\end{array}$ & 13 & 40 & 86 & 0.0013 & $5.93 / 28.3$ & Component of cytoskeleton \\
\hline 11 & Gl: 159129975 & $\begin{array}{l}\text { Aspergillus } \\
\text { fumigatus A1163 }\end{array}$ & $\begin{array}{l}\text { phytanoyl-CoA } \\
\text { dioxygenase family }\end{array}$ & 15 & 64 & 109 & $6.30 \mathrm{E}-06$ & $6.08 / 33.7$ & Oxidization \\
\hline 12 & Gl: 70988713 & $\begin{array}{l}\text { Aspergillus } \\
\text { fumigatus Af293 }\end{array}$ & pectate lyase A & 13 & 44 & 96 & 0.00014 & $6.23 / 33.8$ & $\begin{array}{l}\text { Carbohydrate metabolism, cell wall biogenesis/ } \\
\text { degradation }\end{array}$ \\
\hline 13 & Gl: 71001408 & $\begin{array}{l}\text { Aspergillus } \\
\text { fumigatus Af293 }\end{array}$ & urate oxydase UaZ & 12 & 32 & 80 & 0.0052 & $7.24 / 34.1$ & Metabolism of urate \\
\hline 14 & Gl: 70986899 & $\begin{array}{l}\text { Aspergillus } \\
\text { fumigatus Af293 }\end{array}$ & $\begin{array}{l}\text { malate dehydrogenase, } \\
\text { NAD-dependent }\end{array}$ & 23 & 70 & 258 & $7.90 \mathrm{E}-21$ & $9.08 / 35.8$ & Cellular carbohydrate metabolic process \\
\hline 15 & Gl: 169764553 & $\begin{array}{l}\text { Aspergillus oryzae } \\
\text { RIB40 }\end{array}$ & hypothetical protein & 13 & 41 & 92 & 2.90E-04 & $6.21 / 35.3$ & unknown \\
\hline $\begin{array}{l}16 A- \\
16 B\end{array}$ & Gl: 70982195 & $\begin{array}{l}\text { Aspergillus } \\
\text { fumigatus Af293 }\end{array}$ & $\begin{array}{l}\text { 3-hydroxybutyryl-CoA } \\
\text { dehydrogenase }\end{array}$ & 15 & 44 & 90 & 0.00052 & $6.33 / 36.0$ & Fatty acid metabolic process \\
\hline 17 & Gl: 121711615 & $\begin{array}{l}\text { Aspergillus } \\
\text { clavatus NRRL } 1\end{array}$ & $\begin{array}{l}\text { proteasome component } \\
\text { Pre8, putative }\end{array}$ & 12 & 44 & 80 & 0.0052 & $5.55 / 30.1$ & $\begin{array}{l}\text { Proteolysis involved in cellular protein catabolic } \\
\text { process }\end{array}$ \\
\hline
\end{tabular}




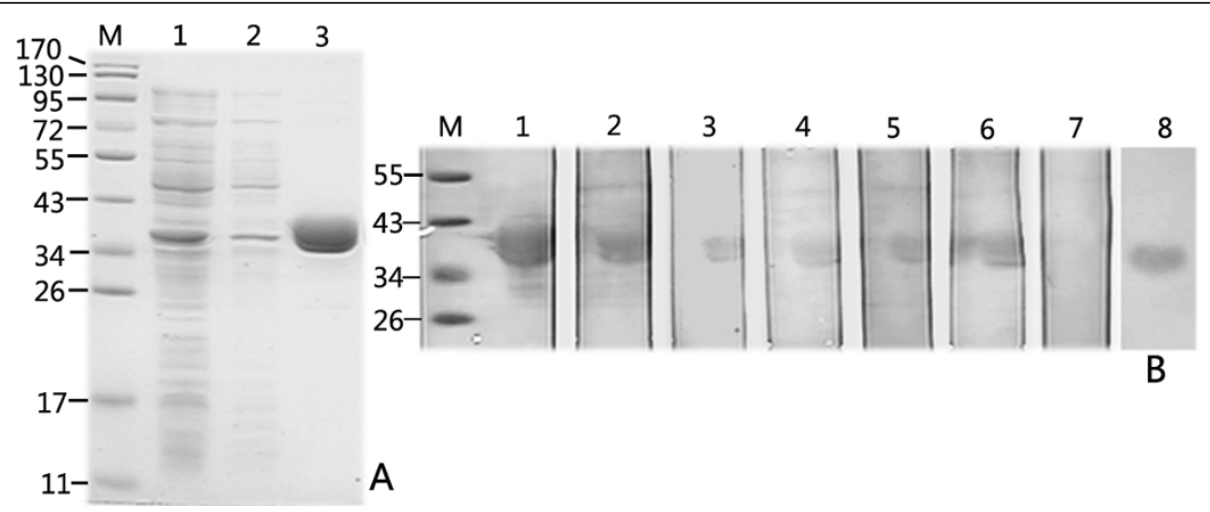

Figure 3 SDS-PAGE and Western blot analysis of the recombinant thioredoxin reductase GliT (TR) of A. fumigatus. (A): SDS-PAGE analysis of the recombinant TR expressed in Escherichia coli BL21. Lane M, molecular weight marker; lane 1, pET28a -TR in E. coli BL21, 1 mM isopropyl- $\beta$ - D - thiogalactoside induced for 5 h; lane 2, pET28a-TR in E. coli BL21, not induced; lane 3, purified recombinant TR; (B): Western blot analysis of the purified recombinant TR with sera of 6 patients with proven IA, pooled control patients, and monoclonal mouse anti-His antibody. lanes 1-6, Western blot of purified recombinant TR with sera from 6 patients with proven IA; lane 7, Western blot of purified recombinant TR with sera of pooled control patients; lane 8 , Western blot of purified recombinant TR with monoclonal mouse anti-His antibody.

an immunogen in patients with systemic candidiasis [32]. Furthermore, diverse groups have reported that some metabolic enzymes interact specifically with human extracellar matrix proteins, such as fibronectin, laminin, and integrin-like vitronectin [33,34], and are involved in adhesion and pathogenesis.

The immunodominant nature of these proteins is valuable for the diagnosis of invasive fungal infections. DppV, a member of the dipeptidyl-peptidase family in A. fumigatus, is identical to one of the principal antigens used in the diagnosis of IA. Moreover, DppV can generate protection responses, and improve the survival rate of Aspergillus-infected mice [28]. DppV can also bind with collagen or other human proteins and degrade them, which can damage the host. Recombinant DppV has shown a great potential in the serodiagnosis of IA in immunocompromised and immunocompetent patients [35]. NAD-dependent malate dehydrogenase, a key enzyme in glycometabolism that catalyze the reversible conversion between malate and oxaloacetate, was reported recently as an allergen of $A$. fumigatus and $A$. versicolor [29]. Malate dehydrogenase was also shown to be a Paracoccidioides brasileinsis immunogenic protein [36] as well as a Candida albicans immunogen [32]. Aspartyl aminopeptidase, an enzyme that specifically degrades only amino-terminal acidic amino acids from peptides, was recently reported as an antigen of $A$. fumigatus [30].

TR of A. fumigatus has been described as an extracellular antigenic protein by two recent studies [30,31]. In one former study, the secreted fraction of two geographically different strains (190/96 and DAYA) of A. fumigatus were used to identify new immunogenic molecules reacting with pooled ABPA patient sera (IgG and IgE). TR was only detected on 2DE immunoblots of the secreted proteome of the DAYA strain probed with the IgE antibody fraction from pooled ABPA patients sera [31]. This result suggested that TR might not be a good biomarker for ABPA. In another study, the immunosecretome of A. fumigatus was detected using pooled patient sera (total $\mathrm{n}=22$ patients [ABPA, $\mathrm{n}=11$; aspergilloma, $\mathrm{n}=5$; IA, $\mathrm{n}=6]$ ). The immunoreactive intensity of TR was lower than most other proteins [30]. A possible explanation is that the anti-TR antibody titers were not high in pooled sera because most cases included in the study were not IA.

Although investigators in other laboratories recently noted the antigenic nature of TR [30,31], no study has found shown diagnostic value for TR in non-neutropenic patients with IA. We showed that TR (spot no. 2A-2 M) had the strongest immunoreactivity with patient sera. TR, a component of the gliotoxin biosynthetic cluster, provides self protection to A. fumigatus against gliotoxin $[37,38]$. This protein has been described as an extracellular protein of A. fumigatus by Singh and Kumar [30,31]. However, Schrettl et al. showed that GliT is preferentially localized in the cytoplasm and nuclei by a GFP-GliT construct [38]. To predict whether or not GliT is actively secreted into the culture supernatant, we used two bioinformatic tools (SignalP and WoLF PSORT) to analyze its localization. Our results support the findings of Singh and Kumar [30,31]. Homology analysis indicated that TR had no match with human proteins, as Kumar et al. [35] reported. Muro et al. [39] also reported that the fungal TR has only $19 \%$ sequence similarity to human TR. Furthermore, sequence homology analysis showed that TR of $A$. fumigatus has low homology with most other Aspergillus species as well as most other fungi. Therefore, TR could be considered as a specific antigen of $A$. fumigatus and as a potential biomarker for the serological diagnosis of IA. In 
order to study its diagnostic potential, we cloned the TR gene and purified the recombinant protein. Immunoblots showed that recombinant protein could be recognized by the sera from all six IA patients. These results suggested that the TR of A. fumigatus could be developed as a biomarker for the diagnosis of IA, especially in critically ill patients.

One of the strengths of our study was that all patients included had histopathologic evidence and positive cultures. This enabled us to discriminate between invasive disease and colonization. However, we do realize that the study design has limitations. We did not further investigate the reactivity of individual patient serum with the extracellular fraction of A. fumigatus, thus we cannot provide data whether or not these proteins consistently react with individual IA patient serum. Moreover, the cases used in this study were limited in number, therefore the diagnostic value of the antigen identified should be validated in further prospective studies using large-scale serum specimens.

\section{Conclusions}

Aspergillus fumigatus is known to be the most common opportunistic pathogen that causes life-threatening IA in humans. The ability of $A$. fumigatus to acquire and process growth substrates from its host is dependent on the factors the fungus releases. Studies on the extracellular proteins of A. fumigatus and their immunogenic potential are therefore important for further understanding the pathogenesis of A. fumigatus and targets for the immunodiagnosis of the diseases. Our study has highlighted the immunodominant antigens of extracellular proteins. A total of 17 proteins of A. fumigatus were identified as antigens in humans. Some of the proteins have been reported as antigens of Aspergillus and/or other fungi. Interestingly, our study revealed the best immunoactive protein, TR, which showed great potential for the diagnosis of IA.

\section{Materials and methods}

\section{Patients and control subjects}

Serum samples expressing high titers of antibodies against the extracellular proteins of $A$. fumigatus were obtained from six non-neutropenic-proven IA patients with different underlying diseases. All serum samples were obtained at the time of diagnosis. Two-to-four samples were obtained sequentially per patient. Sera from $20 \mathrm{ICU}$ patients without clinical or microbiological evidence of IA, including 8 patients with chronic obstructive pulmonary disease, 6 patients with chronic renal disease, 3 patients with renal transplantation, and 3 patients with acute pancreatitis (age range, 33-75 years), were used as negative controls. Two samples were obtained per control patient (one during early admission and one before leaving the hospital). Aspergillus-specific IgG antibodies in the sera of all patients were determined by an indirect ELISA using filtrate proteins of $A$. fumigatus $(1 \mu \mathrm{g} / \mathrm{ml})$ as the coating antigen (sera diluted 1:1000). All sera were stored at $-70^{\circ} \mathrm{C}$. Sera of IA patients and controls were pooled separately for immunoproteomics analysis. According to EORTC-MSG criteria, proven IA refers to histopathologic evidence of tissue invasion by septated, acutely-branching filamentous fungi, together with a positive culture (sputum and/or bronchoalveolar lavage) [39]. The study protocol was approved by the Ethics Committee of the hospital and informed consent was obtained from all patients included in the study.

\section{Preparation of extracellular proteins}

A. fumigatus (strain CMCC (f) A1a) was obtained from the Microbial Culture Collection Management Committee of China, Medical Mycology Center. The fungus was first grown on Sabouraud agar plates at $37^{\circ} \mathrm{C}$ for 3 days. The conidia were collected and incubated in yeast-extract-peptone-glucose (YEPG) broth (1\% yeast extract, $2 \%$ peptone, and $2 \%$ glucose) in a $500-\mathrm{ml}$ flask on a shaker at $37^{\circ} \mathrm{C}$ for 14 days. Then, the culture supernatant was collected by filtration. The proteins were recovered by trichloroacetic acid (TCA) precipitation, as described previously [40]. Finally, the precipitates were resuspended in two-dimensional electrophoresis (2-DE; $7 \mathrm{M}$ urea, $2 \mathrm{M}$ thiourea, $4 \%[\mathrm{w} / \mathrm{v}$ ] CHAPS, $1 \%[\mathrm{w} / \mathrm{v}]$ DTT, $1 \%$ protease inhibitor cocktail $[\mathrm{v} /$ $\mathrm{v}]$, and $2 \%$ [v/v] IPG buffer [pH 3-10]) lysis buffer, and stored at $-70^{\circ} \mathrm{C}$. The protein concentration was determined by the Bradford method using BSA as the standard.

\section{Two-dimensional electrophoresis and Western blot analysis}

Samples containing $150 \mu \mathrm{g}$ of filtrate protein were separated by 2-DE, as described elsewhere [41], using immobilized, non-linear $\mathrm{pH} 3-10$ gradient strips $(24 \mathrm{~cm}$; Amersham Biosciences, Uppsala, Sweden) for isoelectric focusing, and $12.5 \%$ sodium dodecylsulfate polyacrylamide gels for the second dimension separation. All gels were silver-stained according to published procedures [42] or electrotransferred to polyvinylidene fluoride (PVDF) membranes [43]. Three replicates were run for each sample.

Western blot was performed as described previously [44]. Briefly, the membranes were probed with primary antibody (pooled sera of patients with proven IA and pooled control sera [1:1000 dilution in each case]) at $4^{\circ} \mathrm{C}$ overnight. Subsequently, the membranes were thrice washed with Tris-buffered saline ( $\mathrm{pH} 7.5)$ containing 0.05\% (v/v) Tween-20 (TBST) for $10 \mathrm{~min}$ and incubated with horseradish peroxidase (HRP)-conjugated goat antihuman IgG (1:2000 dilution) for $2 \mathrm{~h}$ at room temperature. The membranes were then washed with TBST and the signal was detected with an enhanced chemiluminescence 
detection kit (Amersham Biosciences, Uppsala, Sweden). The autoradiographs were developed using Kodak imaging films according to the instrument of the manufactorer. Three replicates were performed for each sample.

\section{Protein identification and database searches}

The specific immunoreactive protein spots were matched through overlapping images of the blot and gel. The Western blots were matched first with their own Ponceau stain images, then were compared with the silver-stained gel. Subsequently, the spots of interest were excised from the 2DE gels for tryptic in-gel digestion and matrixassisted laser desorption ionization time-of-flight mass spectrometry (MALDI-TOF-MS) on a time-of-flight Ultraflex II mass spectrometer (Bruker Daltonics, Bremen, Germany). The peak lists of each protein spot were searched against the NCBI database using Mascot (v2.1.03; Matrix Sciences, London, UK). The following search parameter criteria were used: significant protein MOWSE score at a $p<0.05$; minimum mass accuracy, 100 ppm; 1 missed cleavage site allowed (cysteine carbamidomethylation, acrylamide-modified cysteine, and methionine oxidation); similarity of $\mathrm{pI}$ and relative molecular mass specified; and minimum sequence coverage of $15 \%$.

\section{Bioinformatics analysis of TR}

The signal peptide and the probability of TR were predicted using SignalP software (http://www.cbs.dtu.dk/services/SignalP/). Another subcellular localization prediction tool, WoLF PSORT (http://www.wolfpsort.org), was used to analyze the amino acid sequences of proteins for prediction of cellular localization. Homology analysis was performed using the BLAST program (http://www.ncbi.nlm. nih.gov/BLASTp and http://www.uniprot.org).

\section{Expression, purification, and Western blot analysis of recombinant thioredoxin reductase GliT}

For RNA preparation, $100 \mathrm{mg}$ of frozen mycelium was ground under nitrogen and the whole RNA was extracted using Trizol (Invitrogen, USA). cDNA was generated using AMV reverse transcriptase (Promega, Madison, WI, USA). The TR gene was amplified using the following primers: 5'-CACACATATGTCGATCGGCAAACTAC-3' and 5'-ACTGAATTCCTATAGCTCCTGATCGAGACG3 '. The resulting 1005-bp fragments were cloned into the pET-28a (+) expression vector (Novagen, Germany). The TR sequence was $100 \%$ identical to the gene of $A$. fumigatus strain Af293. Then, the recombinant $\mathrm{His}_{6}$-TR was expressed in E. coli BL21 competent cells, and purified using a TALON metal affinity resin (Clontech, Japan). Fractions containing the purified TR were pooled, dialyzed against $0.1 \mathrm{M}$ phosphate buffered saline (PBS; pH 7.2), and stored at $-70^{\circ} \mathrm{C}$. Protein identity of the recombinant TR was confirmed by MALDI-TOF MS.
Western blot of the purified recombinant proteins was carried out as described earlier. Monoclonal mouse antiHIS antibody (diluted 1:4000), the serum samples from six patients with proven IA, and pooled sera from healthy individuals (diluted 1:1000) were used as primary antibodies. HRP-rabbit anti-mouse IgG (1:5000) and HRP-goat anti-human IgG (diluted 1:2000) were used as secondary antibodies. The antibody-bound proteins were then visualized using the DAB kit (Maixin_Bio, China).

\section{Additional material}

Additional file 1: Histopathological results of 6 proven IA patients This figure shows the histopathological section of lung tissues obtained from 6 proven IA patients exhibiting Aspergillus with septated and acutely-branching hyphae.

Additional file 2: MS-based identification of all immunoreactive protein of $A$. fumigatus during growth in YEPG medium at $37^{\circ} \mathrm{C}$ for 14 days. This table lists all MS-identified proteins that were marked in Figure 2

Additional file 3: BLAST search of $A$. fumigatus thioredoxin reductase Glit in UniProtKB. This table lists 1000 BLAST results.

Additional file 4: MS spectra of the recombinant thioredoxin reductase Glit. Protein identity of the recombinant thioredoxin reductase Glit was confirmed by MALDI-ToF MS whereby peptides (following tryptic digestion) were identified yielding 13 peptides matched and 37\% sequence coverage.

\section{Abbreviations}

MALDI-TOF: matrix-assisted laser desorption/ionization-time of flight.

\section{Acknowledgements}

We thank Professor Fu-qiang Wang for technical assistance in twodimensional electrophoresis. This work was supported financially by Jiangsu Science Foundation (BE2009673).

\section{Authors' contributions}

FQL conceived, coordinated and designed the study. LNS contributed to the acquisition, analysis and interpretation of data and drafted the manuscript. XXK, SQW and JFL performed the experiment and were involved in drafting the article. $\mathrm{MH}$ and HFS participated in sample collection and data acquisition. All the authors have read and approved the final manuscript.

\section{Competing interests}

The authors declare that they have no competing interests.

Received: 9 August 2011 Accepted: 18 January 2012

Published: 18 January 2012

\section{References}

1. Bulpa PA, Dive AM, Garrino MG, Delos MA, Gonzalez MR, Evrard PA, Glupczynski Y, Installe EJ: Chronic obstructive pulmonary disease patients with invasive pulmonary aspergillosis: benefits of intensive care? Intensive Care Med 2001, 27(1):59-67.

2. Garnacho-Montero J, Amaya-Villar R, Ortiz-Leyba C, Leon C, Alvarez-Lerma F, Nolla-Salas J, Iruretagoyena JR, Barcenilla F: Isolation of Aspergillus spp. from the respiratory tract in critically ill patients: risk factors, clinical presentation and outcome. Crit Care (London, England) 2005, 9(3): R191-R199.

3. Meersseman W, Vandecasteele SJ, Wilmer A, Verbeken E, Peetermans WE, Van Wijngaerden E: Invasive aspergillosis in critically ill patients without malignancy. Am J Respir Crit Care Med 2004, 170(6):621-625. 
4. Vandewoude K, Blot S, Benoit D, Depuydt P, Vogelaers D, Colardyn F: Invasive aspergillosis in critically ill patients: analysis of risk factors for acquisition and mortality. Acta Clin Belg 2004, 59(5):251-257.

5. Vandewoude $\mathrm{KH}$, Blot SI, Benoit D, Colardyn F, Vogelaers D: Invasive aspergillosis in critically ill patients: attributable mortality and excesses in length of ICU stay and ventilator dependence. J Hosp Infect 2004, 56(4):269-276

6. Vandewoude KH, Blot SI, Depuydt P, Benoit D, Temmerman W, Colardyn F Vogelaers D: Clinical relevance of Aspergillus isolation from respiratory tract samples in critically ill patients. Crit Care (London, England) 2006, 10(1):R31.

7. Ader F, Nseir S, Le Berre R, Leroy S, Tillie-Leblond I, Marquette CH, Durocher A: Invasive pulmonary aspergillosis in chronic obstructive pulmonary disease: an emerging fungal pathogen. Clin Microbiol Infect 2005, 11(6):427-429.

8. Chen KY, Ko SC, Hsueh PR, Luh KT, Yang PC: Pulmonary fungal infection: emphasis on microbiological spectra, patient outcome, and prognostic factors. Chest 2001, 120(1):177-184.

9. Khasawneh F, Mohamad T, Moughrabieh MK, Lai Z, Ager J, Soubani AO: Isolation of Aspergillus in critically ill patients: a potential marker of poor outcome. J Crit Care 2006, 21(4):322-327.

10. Prodanovic H, Cracco C, Massard J, Barrault C, Thabut D, Duguet A, Datry A, Derenne JP, Poynard T, Similowski T: Invasive pulmonary aspergillosis in patients with decompensated cirrhosis: case series. BMC Gastroenterol 2007, 7:2.

11. Sessa A, Meroni M, Battini G, Pitingolo F, Giordano F, Marks M, Casella P: Nosocomial outbreak of Aspergillus fumigatus infection among patients in a renal unit? Nephrol Dial Transplant 1996, 11(7):1322-1324.

12. Sahlen AO, Suvarna SK, Wilkie ME: A case of invasive pulmonary aspergillosis in renal failure. Nephrol Dial Transplant 2004, 19(10):2687.

13. ter Maaten JC, Golding RP, van Schijndel RJ, Strack, Thijs LG: Disseminated aspergillosis after near-drowning. Neth J Med 1995, 47(1):21-24.

14. Vieira DF, Van Saene HK, Miranda DR: Invasive pulmonary aspergillosis after near-drowning. Intensive Care Med 1984, 10(4):203-204.

15. Leroy P, Smismans A, Seute T: Invasive pulmonary and central nervous system aspergillosis after near-drowning of a child: case report and review of the literature. Pediatrics 2006, 118(2):e509-e513.

16. Trof RJ, Beishuizen A, Debets-Ossenkopp YJ, Girbes AR, Groeneveld AB: Management of invasive pulmonary aspergillosis in non-neutropenic critically ill patients. Intensive Care Med 2007, 33(10):1694-1703.

17. Mennink-Kersten MA, Donnelly JP, Verweij PE: Detection of circulating galactomannan for the diagnosis and management of invasive aspergillosis. Lancet Infect Dis 2004, 4(6):349-357.

18. Dagenais TR, Keller NP: Pathogenesis of Aspergillus fumigatus in Invasive Aspergillosis. Clin Microbiol Rev 2009, 22(3):447-465.

19. Balloy V, Huerre M, Latge JP, Chignard M: Differences in patterns of infection and inflammation for corticosteroid treatment and chemotherapy in experimental invasive pulmonary aspergillosis. Infect Immun 2005, 73(1):494-503.

20. Rementeria A, Lopez-Molina N, Ludwig A, Vivanco AB, Bikandi J, Ponton J, Garaizar J: Genes and molecules involved in Aspergillus fumigatus virulence. Rev Iberoam Micol 2005, 22(1):1-23.

21. Nierman WC, Pain A, Anderson MJ, Wortman JR, Kim HS, Arroyo J, Berriman M, Abe K, Archer DB, Bermejo C, et al: Genomic sequence of the pathogenic and allergenic filamentous fungus Aspergillus fumigatus. Nature 2005, 438(7071):1151-1156.

22. Galagan JE, Calvo SE, Cuomo C, Ma LJ, Wortman JR, Batzoglou S, Lee SI, Basturkmen M, Spevak CC, Clutterbuck J, et al: Sequencing of Aspergillus nidulans and comparative analysis with A. fumigatus and A. oryzae. Nature 2005, 438(7071):1105-1115.

23. Machida M, Asai K, Sano M, Tanaka T, Kumagai T, Terai G, Kusumoto K, Arima T, Akita O, Kashiwagi Y, et al: Genome sequencing and analysis of Aspergillus oryzae. Nature 2005, 438(7071):1157-1161.

24. Payne GA, Nierman WC, Wortman JR, Pritchard BL, Brown D, Dean RA, Bhatnagar D, Cleveland TE, Machida M, Yu J: Whole genome comparison of Aspergillus flavus and A. oryzae. Med Mycol 2006, 44:S9-S11.

25. Pel HJ, de Winde JH, Archer DB, Dyer PS, Hofmann G, Schaap PJ, Turner G, de Vries RP, Albang R, Albermann K, et al: Genome sequencing and analysis of the versatile cell factory Aspergillus niger CBS 513.88. Nat Biotechnol 2007, 25(2):221-231.
26. Haynes KA, Latge JP, Rogers TR: Detection of Aspergillus antigens associated with invasive infection. J Clin Microbiol 1990, 28(9):2040-2044.

27. Yu B, Niki Y, Armstrong D: Use of immunoblotting to detect Aspergillus fumigatus antigen in sera and urines of rats with experimental invasive aspergillosis. J Clin Microbiol 1990, 28(7):1575-1579.

28. Beauvais $\mathrm{A}$, Monod M, Debeaupuis JP, Diaquin M, Kobayashi $\mathrm{H}$, Latge JP: Biochemical and antigenic characterization of a new dipeptidylpeptidase isolated from Aspergillus fumigatus. J Biol Chem 1997, 272(10):6238-6244.

29. Benndorf D, Muller A, Bock K, Manuwald O, Herbarth O, von Bergen M: Identification of spore allergens from the indoor mould Aspergillus versicolor. Allergy 2008, 63(4):454-460

30. Kumar A, Ahmed R, Singh PK, Shukla PK: Identification of virulence factors and diagnostic markers using immunosecretome of Aspergillus fumigatus. J Proteomics 2011, 74(7):1104-1112.

31. Singh B, Oellerich M, Kumar R, Kumar M, Bhadoria DP, Reichard U, Gupta VK, Sharma GL, Asif AR: Immuno-reactive molecules identified from the secreted proteome of Aspergillus fumigatus. J Proteome Res 2010, 9(11):5517-5529.

32. Pitarch A, Abian J, Carrascal M, Sanchez M, Nombela C, Gil C: Proteomicsbased identification of novel Candida albicans antigens for diagnosis of systemic candidiasis in patients with underlying hematological malignancies. Proteomics 2004, 4(10):3084-3106.

33. Gozalbo D, Gil-Navarro I, Azorin I, Renau-Piqueras J, Martinez JP, Gil ML: The cell wall-associated glyceraldehyde-3-phosphate dehydrogenase of Candida albicans is also a fibronectin and laminin binding protein. Infect Immun 1998, 66(5):2052-2059.

34. Klotz SA, Pendrak ML, Hein RC: Antibodies to alpha5beta1 and alpha(v) beta3 integrins react with Candida albicans alcohol dehydrogenase. Microbiol (Reading, England) 2001, 147(Pt 11):3159-3164.

35. Sarfati J, Monod M, Recco P, Sulahian A, Pinel C, Candolfi E, Fontaine T, Debeaupuis JP, Tabouret M, Latge JP: Recombinant antigens as diagnostic markers for aspergillosis. Diagn Microbiol Infect Dis 2006, 55(4):279-291.

36. da Fonseca CA, Jesuino RS, Felipe MS, Cunha DA, Brito WA, Soares CM: Two-dimensional electrophoresis and characterization of antigens from Paracoccidioides brasiliensis. Microbes Infect 2001, 3(7):535-542.

37. Scharf DH, Remme N, Heinekamp T, Hortschansky P, Brakhage AA, Hertweck C: Transannular disulfide formation in gliotoxin biosynthesis and its role in self-resistance of the human pathogen Aspergillus fumigatus. J Am Chem Soc 2010, 132(29):10136-10141.

38. Schrettl M, Carberry S, Kavanagh K, Haas H, Jones GW, O'Brien J, Nolan A, Stephens J, Fenelon O, Doyle S: Self-protection against gliotoxin-a component of the gliotoxin biosynthetic cluster, GliT, completely protects Aspergillus fumigatus against exogenous gliotoxin. PLOS Pathog 2010, 6(6):e1000952.

39. De Pauw B, Walsh TJ, Donnelly JP, Stevens DA, Edwards JE, Calandra T, Pappas PG, Maertens J, Lortholary O, Kauffman CA, et al: Revised definitions of invasive fungal disease from the European Organization for Research and Treatment of Cancer/Invasive Fungal Infections Cooperative Group and the National Institute of Allergy and Infectious Diseases Mycoses Study Group (EORTC/MSG) Consensus Group. Clin Infect Dis 2008, 46(12):1813-1821.

40. Medina ML, Francisco WA: Isolation and enrichment of secreted proteins from filamentous fungi. Methods Mol Biol (Clifton, NJ) 2008, 425:275-285.

41. Wu J, Wang F, Gong Y, Li D, Sha J, Huang X, Han X: Proteomic analysis of changes induced by nonylphenol in Sprague-Dawley rat Sertoli cells. Chem Res Toxicol 2009, 22(4):668-675.

42. Shevchenko A, Wilm M, Vorm O, Mann M: Mass spectrometric sequencing of proteins silver-stained polyacrylamide gels. Anal Chem 1996, 68(5):850-858

43. Towbin H, Staehelin T, Gordon J: Electrophoretic transfer of proteins from polyacrylamide gels to nitrocellulose sheets: procedure and some applications. Proc Natl Acad Sci USA 1979, 76(9):4350-4354.

44. Laemmli UK: Cleavage of structural proteins during the assembly of the head of bacteriophage T4. Nature 1970, 227(5259):680-685.

doi:10.1186/1471-2180-12-11

Cite this article as: Shi et al: Immunoproteomics based identification of thioredoxin reductase GliT and novel Aspergillus fumigatus antigens for serologic diagnosis of invasive aspergillosis. BMC Microbiology 2012 12:11. 